\title{
Viewing the Ediacaran Biota as a failed experiment is unhelpful
}

2

\author{
1) School of Earth Sciences, University of Bristol, Life Sciences Building, 24 Tyndall \\ Avenue, Bristol, BS8 1TQ U.K. \\ 2) Department of Earth Sciences, University of Cambridge, Downing Street, Cambridge, \\ CB2 3EQ, U.K.

\section{*author for correspondence}

Throughout the history of their study, macroscopic organisms from the late Ediacaran Period have often been described as failed experiments in the history of life. Such discussion of the Ediacaran Macrobiota hinders efforts to determine their evolutionary significance. We argue that the field of Ediacaran palaeobiology should dispense with unhelpful historical classification schemes and embrace phylogenetic systematics if we are to successfully establish the evolutionary relevance of these fossils.

The Ediacaran Macrobiota - an assortment of macroscopic, largely soft-bodied organisms that lived during the $\sim 30$-million-year interval prior to the Cambrian Period - have long been considered a palaeontological conundrum. Many fossils of these organisms exhibit unusual body plans that are unlike anything seen amongst living taxa (Fig. 1A-D), and it has proven difficult to resolve their relationships to extant groups. Individually and collectively, members of the Ediacaran Macrobiota have been both allied with extant clades, and deliberately set apart from them by suggestions that they were either 'failed experiments' in the history of life, or members of long-extinct higher-order clades ${ }^{1}$. Despite their undoubted value in stimulating debate around these taxa, we argue that these latter viewpoints have hampered Ediacaran research. They have also created confusion within the wider community as to the placement of the Ediacaran Macrobiota in the tree of life, forming a barrier to their incorporation within biological and developmental discussions. We advocate abandoning the failed experiment perspective, and embracing phylogenetic thinking in order to make progress in determining the phylogenetic positions of these organisms, and realising their evolutionary significance. 
Unusual macroscopic impressions were described from bedding planes in what are now known to be Ediacaran-age strata from the 1840s onwards, but until the late 1950s it was held that such impressions could not represent Precambrian fossils. The prevailing wisdom suggested that all Precambrian rocks were 'Azoic', and pre-dated life, so the impressions were largely considered to represent either sedimentary structures, or fossils within younger, Palaeozoic rocks. This situation changed following the seminal description of Charnia masoni from Charnwood Forest, UK in 1958², and recognition that these fossils predated the famous 'Cambrian Explosion' and had a global distribution. Subsequently, the fossils began to be colloquially referred to as the Ediacara biota (later Ediacaran biota), after the Ediacara Hills locality in South Australia.

As taxa were formally described throughout the 1960s and 1970s, members of the Ediacaran biota were frequently considered to belong to derived animal clades including the pennatulacean cnidarians ${ }^{3}$ and the annelid worms ${ }^{4}$, although non-metazoan opinions were occasionally expressed. During the 1970s and 1980s, these hypotheses were challenged by a school of thought that sought to remove the Ediacaran biota from extant higher-order groupings and place them within new phyla or kingdoms. Phylum Petalonamae ${ }^{5}$ ('Nama petals', named by Hans Pflug after fossils described from the Nama desert of Namibia) included several frondose taxa (e.g. Charnia) and was initially considered to represent ancient animals, but was later revised to lie intermediate to the animal and plant Kingdoms and distinct from all living forms ${ }^{6}$. Pflug used the term Petalo-organisms to describe a grade of organisation, including the Petalonamae (with an anatomy closer to animals than plants) and Petalostromae (with an anatomy closer to plants than animals) ${ }^{6}$ (Fig. 2D). A recent study has placed Phylum Petalonamae as sister to the Eumetazoa, but includes a broader suite of taxa than were originally recognised by Pflug 7 . Phylum Proarticulata ${ }^{8,9}$ included taxa such as Dickinsonia, and was considered to comprise a clade of bilaterian animals with similarities to the (now defunct) Superphylum 'Articulata'10. Mikhail Fedonkin envisaged a situation in which truly segmented animals (Articulata) evolved from Ediacaran organisms with an offset form of bilateral symmetry, which themselves derived from radially symmetrical ancestors he considered related to jellyfish ${ }^{8}$ (Fig. 2B). The radical Vendobiont hypothesis of Adolf Seilacher ${ }^{11,12}$ united all Ediacaran taxa that displayed a 'serially quilted' anatomy (including those listed above) within Kingdom Vendobionta (meaning 'Vendian Life' after the Russian stratigraphic term for the latest Precambrian), on the basis of taphonomic and constructional 
arguments. Seilacher and colleagues later modified these views, first revising Kingdom Vendobionta to an extinct sister-Phylum to the Eumetazoa ${ }^{13}$, before considering vendobionts as an extinct Class $^{14}$ or Subclass ${ }^{15}$ of giant protists (Fig. 2C). This repeated revision may have been due to Seilacher's recognition that an extinct higher order clade was an unsatisfactory solution ${ }^{13,14}$ to the Ediacaran problem. Despite the radical nature of these hypotheses, they initially attracted considerable support, although questions were raised as to whether there was sufficient evidence to support the Vendobiont hypothesis, with alternative suggestions that the Ediacaran biota may simply represent a subset of Neoproterozoic biodiversity ${ }^{16}$.

\section{Breaking up the Ediacaran biota}

80 In challenging earlier metazoan interpretations, the hypotheses of the 1970s and 1980s brought the Ediacaran Macrobiota to the attention of the wider scientific community, and laid the foundations for subsequent debate on their phylogenetic placement. A wealth of anatomical, palaeoecological and developmental specimen data has resulted from these investigations, and the majority of scientists now consider the Ediacaran Macrobiota to be a polyphyletic grouping ${ }^{17,18}$. Some taxa are reasonably considered to be candidate metazoans, most notably Dickinsonia, whose metazoan placement is now supported by developmental, ichnological and biomarker studies ${ }^{19-22}$, whereas others are allied with non-metazoan eukaryotic groups, such as the protistan-grade Palaeopascichnus ${ }^{23}$, or Beltanelliformis interpreted as a cyanobacterial colony ${ }^{24}$. Today, as consensus tends away from a clade of the Ediacaran Macrobiota, undermining the previously defined higher-order groupings (though with some exceptions, e.g. 7), many researchers continue to cite Seilacher, Pflug and Fedonkin's works as a mechanism to demonstrate the idiosyncratic nature of these fossils. There is a particular tendency to cite only Seilacher's early work, asserting his idea that the Ediacaran Macrobiota could represent an extinct Kingdom as a viable hypothesis, while often neglecting his later publications and taxonomic revisions, and overlooking the fact that he himself acknowledged the presence of metazoans (in the form of ichnofossils, and macrofossils like Kimberella) amongst Ediacaran fossil assemblages ${ }^{11,14}$. Several studies also continue to advance the view that the Ediacaran Macrobiota are failed experiments by virtue of being extinct and not possessing known direct (living) descendants ${ }^{1,25}$. We argue that continued consideration of this viewpoint is detrimental to efforts to advance knowledge of 
104 Macrofossils from the Ediacaran Period may well be strange, and many taxa remain difficult to interpret, but they can, and should, be interpreted within the framework of phylogenetic thinking ${ }^{16}$. Subjecting problematic fossils to hypotheses that displace them from extant groupings is not uncommon, as exemplified by the Cambrian organisms of the Burgess Shale (Fig. 1E-F). Stephen Jay Gould, amongst others, noted the unique anatomies of many fossils of the Burgess Shale, which he did not recognise in any extant animal phyla. Notably, rather than viewing these 'weird wonders' as failed experiments, Gould recognised the significance of the strange Cambrian taxa, some of which he did not consider to sit within any known animal phyla "of this or any former Earth" (26, p. 134). Furthermore, study of these unusual organisms has gradually resolved their relations to extant clades, as application of the stem and crown group concept permeated invertebrate palaeontological research ${ }^{27}$.

116 If we accept that life has a single origin (Fig. 2A), Ediacaran macrofossils must occupy a 117 branch/branches in the known tree of life. Any phylogenetic framework must reflect 118 contemporary knowledge, such that proposed Ediacaran clades are grounded in current 119 phylogenetic consensus. For example, the Proarticulata were considered ancestors to the 120 Articulata, a group that molecular data now suggest to be invalid ${ }^{9}$, with metazoan segmentation evolving independently at least three times ${ }^{28}$. Only when the correct phylogenetic position(s) for the Ediacaran Macrobiota has been established can their evolutionary success or failure be assessed (Fig. 2). Evolutionary success can be measured in many ways, and does not necessarily correlate with survivorship: were trilobites an evolutionary failure? If these organisms are resolved as being either paraphyletic, or a polyphyletic assemblage 17,18,29,30, it would be inappropriate to consider them a failed experiment, and in time we may consider some of the characters they possess (such as axial arrangement) as homologous with those of extant taxa. We recognise that at least some of the Ediacaran taxa were members of groups with extant representatives, including both metazoan (e.g. Dickinsonia) and non-metazoan clades (e.g. Palaeopascichnus). They persisted for 30 million years, with evidence for considerable diversification, and they display the capacity to form complex ecosystems ${ }^{31,32}$. At their zenith, the Ediacaran

133 Macrobiota were arguably hugely successful, but we cannot rationalise any of these 134 observations until the ultimate positions of the Ediacaran Macrobiota in phylogeny are 135 known. 
138 As the relatively young field of Ediacaran research continues to make rapid advances, we propose that Ediacaran macrofossil taxa should be considered on a case-by-case basis, with no underlying assumption of monophyly of the Ediacaran Macrobiota. We advocate moving away from the use of leading terminology, which either deliberately divorces members of the Ediacaran Macrobiota from living taxa, or asserts unproven relationships.

Assertion of whether or not the Ediacaran Macrobiota represent failed experiments is premature while their phylogenetic positions remain unknown. We must also remember that if we are to fully appreciate the information these taxa can provide, we should define them not only by what sets them apart, but also by similarities to living forms. Future work detailing specific hypotheses of affinity should be based on positive evidence wherever possible, and be grounded in phylogenetic systematics, with careful consideration of a broad suite of characters, integrating across anatomical, developmental and reproductive data, and recognising the impact of different taphonomic regimes.

Holistic combination of such biological and palaeontological data offers our best route towards elucidating the early history of complex macroscopic organisms. The Ediacaran Macrobiota must be restored to the known tree of life.

Acknowledgements: The authors thank D. Grazhdankin and P. Donoghue for constructive discussion.

References:

1. Shen, B., Dong, L., Xiao, S. and Kowalewski, M. The Avalon explosion: evolution of

2. Ford, T.D. Pre-Cambrian fossils from Charnwood forest. Proceedings of the Yorkshire Australia. Palaeontology, 9, 599-628, (1966). 
4. Wade, M.F. Dickinsonia: polychaete worms from the late Precambrian Ediacara fauna, South Australia. Memoirs of the Queensland Museum, 16, 171-190, (1972).

5. Pflug, H.D. Systematik der jung-präkambrischen Petalonamae Pflug 1970. Paläontologische Zeitschrift, 46, 56-67, (1972).

6. Pflug, H.D. Zur fauna der Nama-Schichten in Sudwest-Afrika. IV. Mikroskopische Anatomie der Petalo-Organismen. Palaeontographica A. 139, 166-202, (1973)

8. Fedonkin, M.A. Precambrian metazoans: the problems of preservation, systematics and evolution. Phil. Trans. R. Soc. Lond. B, 311, 27-45, (1985).

7. Hoyal Cuthill, J.F. and Han, J. Cambrian petalonamid Stromatoveris phylogenetically links Ediacaran biota to later animals. Palaeontology (2018).

3

85

$$
\text { and evolution. Phil. Trans. R. Soc. Lond. B, 311, 27-45, (1985). }
$$

9. Fedonkin, M.A. Organic world of the Vendian. Itogi Nauki i Tekhniki, seriya Stratigrafiya, Paleontologiya, 12, 1-127, (1983).

10. Edgecombe, G.D. Palaeontological and molecular evidence linking arthropods,

onychophorans, and other Ecdysozoa. Evolution: Education and Outreach, 2, 178, (2009).
11. Seilacher, A. Vendozoa: organismic construction in the Proterozoic biosphere. Lethaia, 22, 229-239, (1989).

6

12. Seilacher, A. Vendobionta and Psammocorallia: lost constructions of Precambrian evolution. Journal of the Geological Society, 149, 607-613 (1992).

13. Buss, L.W. and Seilacher, A. The Phylum Vendobionta: a sister group of the Eumetazoa? Paleobiology, 20, 1-4, (1994) 
15. Seilacher, A., 2007. The nature of vendobionts. Geological Society, London, Special Publications, 286, 387-397, (2007).

16. Runnegar, B. Vendobionta or Metazoa? Developments in understanding the Ediacara "fauna". Neues Jahrbuch für Geologie und Paläontologie-Abhandlungen, 303-318, (1995).

17. Xiao, S. and Laflamme, M. On the eve of animal radiation: phylogeny, ecology and evolution of the Ediacara biota. Trends in Ecology \& Evolution, 24, 31-40, (2018).

18. Erwin, D.H., Laflamme, M., Tweedt, S.M., Sperling, E.A., Pisani, D. and Peterson, K.J. The Cambrian conundrum: early divergence and later ecological success in the early history of animals. Science, 334, 1091-1097, (2011).

19. Ivantsov, A.Yu. and Malakhovskaya, Y.E. Giant traces of Vendian animals. In Doklady Earth Sciences: Doklady-Akademiia Nauk, 385, 618-622, (2002)

20. Gold, D.A., Runnegar, B., Gehling, J.G. and Jacobs, D.K. Ancestral state reconstruction of ontogeny supports a bilaterian affinity for Dickinsonia. Evolution \& Development, 17, 315-324, (2015).

21. Hoekzema, R.S., Brasier, M.D., Dunn, F.S. and Liu, A.G. Quantitative study of developmental biology confirms Dickinsonia as a metazoan. Proc. R. Soc. B, 284, p.20171348, (2017).

22. Bobrovskiy, I., Hope, J.M., Ivantsov, A., Nettersheim, B.J., Hallmann, C. and Brocks, J.J. Ancient steroids establish the Ediacaran fossil Dickinsonia as one of the earliest animals. Science, 361, pp.1246-1249, (2018).

23. Kolesnikov, A.V., Rogov, V.I., Bykova, N.V., Danelian, T., Clausen, S., Maslov, A.V. and Grazhdankin, D.V. The oldest skeletal macroscopic organism Palaeopascichnus linearis. Precambrian Research, 316, 24-37, (2018). 
24. Bobrovskiy, I., Hope, J.M., Krasnova, A., Ivantsov, A. and Brocks, J.J. Molecular fossils from organically preserved Ediacara biota reveal cyanobacterial origin for Beltanelliformis. Nature Ecology \& Evolution, 2, 437, (2017).

25. Bamforth, E.L. and Narbonne, G.M. New Ediacaran rangeomorphs from Mistaken Point, Newfoundland, Canada. Journal of Paleontology, 83, 897-913, (2009).

26. Gould, S.J. Wonderful life: the Burgess Shale and the nature of history. WW Norton \& Company, 347 pages, (1989).

27. Brysse, K. From weird wonders to stem lineages: the second reclassification of the Burgess Shale fauna. Studies in History and Philosophy of Science Part C: Studies in History and Philosophy of Biological and Biomedical Sciences, 39, 298-313, (2008).

28. Chipman, A.D. Parallel evolution of segmentation by co-option of ancestral gene regulatory networks. Bioessays, 32, 60-70, (2010).

29. Grazhdankin, D. Patterns of evolution of the Ediacaran soft-bodied biota. Journal of Paleontology, 88, 269-283, (2014).

30. Tarhan, L.G., Droser, M.L., Cole, D.B. and Gehling, J.G. Ecological Expansion and Extinction in the Late Ediacaran: Weighing the Evidence for Environmental and Biotic Drivers. Integrative and comparative biology, 58, 688-702, (2018).

31. Mitchell, E.G. and Butterfield, N.J. Spatial analyses of Ediacaran communities at Mistaken Point. Paleobiology, 44, 40-57, (2018).

32. Darroch, S.A., Laflamme, M. and Wagner, P.J. High ecological complexity in benthic Ediacaran communities. Nature Ecology \& Evolution, 17, 1, (2018).

33. Dong, X.P., Donoghue, P.C., Cunningham, J.A., Liu, J.B. and Cheng, H. The anatomy, affinity, and phylogenetic significance of Markuelia. Evolution \& development, 7, 468482, (2005).

34. Ivantsov, A.Y. Small Vendian transversely articulated fossils. Paleontological Journal, 41, 113-122, (2007). 
35. Williams, T.A., Foster, P.G., Cox, C.J. and Embley, T.M. An archaeal origin of eukaryotes supports only two primary domains of life. Nature, 504, 231-236, (2013).

36. Baldauf, S.L. and Palmer, J.D. Animals and fungi are each other's closest relatives: congruent evidence from multiple proteins. Proceedings of the National Academy of Sciences, 90, 11558-11562, (1993).

Figure 1: Members of the Ediacaran Macrobiota (A-D) and Cambrian 'weird wonders' (E-F). A) Charnia masoni from the White Sea region of Russia (PIN 3993-7018). B) Spriggina floundersi from South Australia (SAM P40137). C) Dickinsonia costata from South Australia (SAM P34224). D) Ernietta plateauensis from Namibia. All have been considered vendobionts, Charnia and Ernietta were considered petalonamids, and Spriggina and Dickinsonia were considered proarticulates ${ }^{34}$. E) Halkieria evangelista from Sirius Passet, Greenland. H. evangelista was described after publication of Gould's 'Wonderful Life', but has courted phylogenetic controversy, and is often grouped with the Wiwaxiids. (F) Wiwaxia corrugata from the Burgess Shale (BRSUG 13384). Images provided D. Grazhdankin (A), M. Laflamme (D), and J. Vinther (E).

Figure 2: How cladistic thinking affects our view of the Ediacaran Macrobiota. Crosses indicate nodes that are no longer supported, orange labels are proposed Ediacaran clades, red labels indicate clades that are now defunct. A) Molecular phylogenies predict a single origin of life, and therefore all organisms must fall within the known tree of life ${ }^{35}$. B) The Proarticulata (as originally defined) cannot be reconciled with modern phylogenetic thinking, since the group to which it was most closely allied - the Articulata - has been rejected ${ }^{10}$. C) Previously hypothesised higher-order positions for the Vendobionta ultimately resolve them as either stem-group metazoans or eumetazoans ${ }^{11-13}$, which remain viable phylogenetic hypotheses, or later as protists similar to xenophyophores ${ }^{14-15}$ (dates indicated). D) The petalo-organisms, as conceived by Pflug, represent a grade of organisation between the animals and the plants, encompassing the Petalonamae and Petalostromae, which he interpreted as clades. Molecular phylogenetics has shown that the animal and plant Kingdoms are not sister clades ${ }^{36}$. 
